\title{
Predictive role of vascular endothelial growth factor polymorphisms in the survival of renal cell carcinoma patients
}

\author{
Y.-Q. Yang' and J. Chen ${ }^{2}$ \\ ${ }^{1}$ Medicine Pharmacy, PLA General Hospital, Beijing, China \\ ${ }^{2}$ Children's Nutrition Research Center, \\ Children's Hospital of Chongqing Medical University, Chongqing, China \\ Corresponding author: J. Chen \\ E-mail: chengjie_811@163.com
}

Genet. Mol. Res. 13 (3): 5011-5017 (2014)

Received June 24, 2013

Accepted November 28, 2013

Published July 4, 2014

DOI http://dx.doi.org/10.4238/2014.July.4.16

ABSTRACT. We conducted a study to investigate the possible role of the vascular endothelial growth factor (VEGF) polymorphisms $-2578 \mathrm{C} / \mathrm{A},-1154 \mathrm{G} / \mathrm{A}$ and $-634 \mathrm{C} / \mathrm{G}$ and clinical factors in renal cell carcinoma (RCC) prognosis in a cohort of $336 \mathrm{RCC}$ cases. A total of 336 patients with RCC were recruited from PLA General Hospital between January 2004 and December 2005. All patients were followed up until December 2010, and no patient was lost to follow-up. The follow-up time of this study was 60 months. At the time of analysis, a total of 210 died during the follow-up. The median overall survival for patients was 29.1 months $(95 \% \mathrm{CI}=17.1$ to 41.3 months $)$, and the 5 -year survival rate for the patients was $37.5 \%$. Our study showed that Karnofsky performance status $\geq 60$ could delay death from RCC, with HR $(95 \% \mathrm{CI})$ of 0.57 (0.39-0.84). Patients with anemia, platelet count $>400 \times 10^{9} / \mathrm{L}$, neutrophilia and lymphocytes $>160 \mathrm{~g} / \mathrm{L}$ had increased risk of death from RCC, with HR (95\%CI) of 1.84 (1.18-2.96), 2.01 (1.27-3.25), 1.65 (1.03-2.56) and 1.49 (0.99-2.71), respectively. The VEGF -2578AA and -1154AA genotypes were significantly associated 
with a poor overall survival of RCC patients, with $\mathrm{HR}(95 \% \mathrm{CI})$ of 2.41 (1.32-5.13) and 3.77 (1.42-15.67), respectively. In conclusion, our study presented the factors regarding the prognosis of RCC patients, and high platelet and neutrophil counts, low lymphocytes, and VEGF -2578C/A and $-1154 \mathrm{G} / \mathrm{A}$ polymorphisms were shown to be independent factors for a lower prognosis of RCC patients.

Key words: Renal cell carcinoma; VEGF polymorphism; Prognosis; Predictive factors

\section{INTRODUCTION}

Renal cell carcinoma (RCC) remains the most frequently occurring cancer in the kidney. Epidemiologic studies suggest a continued rise in the incidence and mortality of renal cell carcinomas worldwide over the last 30 years, particularly in the Western world where it has been among the tumors with the highest upward trend in incidence (Mathew et al., 2002; Hollingsworth et al., 2006). Although most patients with early-stage RCC can be cured surgically, approximately $33 \%$ of patients present metastatic disease for which treatment is usually not curative (Motzer et al., 1996). Moreover, about 50\% of RCC patients with curative surgery may be expected to develop a recurrence with distant metastases, and the prognosis of RCC patients with metastatic or recurrent diseases is poor, with a 5 -year survival of less than 20\%. Previous studies have indicated an improved prognosis of RCC by targeting a number of growth factors, such as vascular endothelial growth factor (VEGF) and platelet-derived growth factor and their receptors (Motzer et al., 2007; Patard et al., 2008).

It is reported that VEGF is overexpressed in RCC tissues when compared with normal renal tissues (Langsenlehner et al., 2008). Therapeutic targeting of VEGF has shown preliminary clinical efficacy in RCC (Jäkel et al., 2012; Vrdoljak et al., 2013). Given the possible influence of VEGF levels on treatment efficacy in RCC, VEGF polymorphisms may have an association with risk of RCC patients. Two previous studies conducted in Japan and Spain demonstrated that VEGF polymorphisms may have effects on RCC progression or prognosis (Kawai et al., 2007; Sáenz-López et al., 2013). But the results are inconsistent, and another study has suggested that VEGF gene polymorphisms are not associated with RCC risk (Matthew et al., 2002). Therefore, we conducted a study to investigate the possible role of the VEGF polymorphisms $-2578 \mathrm{C} / \mathrm{A},-1154 \mathrm{G} / \mathrm{A}$ and $-634 \mathrm{C} / \mathrm{G}$ and clinical factors in $\mathrm{RCC}$ prognosis in a cohort of $336 \mathrm{RCC}$ cases.

\section{MATERIAL AND METHODS}

A total of 336 patients with RCC were recruited from the PLA General Hospital between January 2004 and December 2005. All RCC patients were histologically diagnosed, had no prior history of cancer, and were absence of significant cardiac disease and no recent surgery. All the patients were followed up until December 2010, and no patient was lost to follow-up. The study was approved by the Institutional Ethics Committee and informed consent for participating in this study was obtained for each case. 


\section{Data collection}

We collected data regarding demographic and clinical characteristics, baseline biochemical parameters, and date of death or last follow-up. The overall survival was defined as the time from initiation of treatment to the date of death or last follow-up.

\section{Blood samples and genotyping}

All participants were asked to provide $5 \mathrm{~mL}$ blood, and the blood samples were stored at $-20^{\circ} \mathrm{C}$. Genomic DNA for VEGF $-2578 \mathrm{C} / \mathrm{A},-1154 \mathrm{G} / \mathrm{A}$ and $-634 \mathrm{C} / \mathrm{G}$ analysis was extracted using the Qiagen Blood kit (Qiagen, Chastworth, CA, USA) according to manufacturer instructions. Polymerase chain reaction (PCR) combined with restriction fragment length polymorphism assay was used for genotyping. The primers and probes of VEGF $-2578 \mathrm{C} / \mathrm{A},-1154 \mathrm{G} / \mathrm{A}$ and $-634 \mathrm{C} / \mathrm{G}$ were designed using the Sequenom Assay Design 3.1 software (Sequenom, San Diego, CA, USA). PCR was conducted using 5 ng genomic DNA in a 5- $\mu \mathrm{L}$ reaction mixture in the GeneAmp ${ }^{\circledR}$ PCR System 9700 with Dual 384-Well Sample Block Module (Applied Biosystems, Carlsbad, CA, USA). PCR amplifications were conducted with 1-15 ng DNA from all blood samples, using 1.0 U/mL HotStar Taq DNA polymerase (Qiagen, St. Louis, MO, USA), $0.21 \mu \mathrm{M}$ forward and reverse primers, and $0.125 \mathrm{mM}$ dNTPs. The amplification protocol was $95^{\circ} \mathrm{C}$ for $15 \mathrm{~min}$, followed by 35 cycles at $94^{\circ} \mathrm{C}$ for $1 \mathrm{~min}, 55^{\circ} \mathrm{C}$ for $1 \mathrm{~min}$, and $72^{\circ} \mathrm{C}$ for $1 \mathrm{~min}$, with a final extension at $72^{\circ} \mathrm{C}$ for $10 \mathrm{~min}$. For quality control, we randomly selected $10 \%$ of the cases and controls to genotype again by different researchers, and the reproducibility was $100 \%$.

\section{Statistical analysis}

All statistical analyses were performed with the Statistical Package for the Social Sciences (SPSS) Version 16.0 software (SPSS Inc., Chicago, IL, USA). Continuous variables are reported as means \pm standard deviation (SD), while categorical variables are shown as frequencies and percentages. Distributions of overall survival were estimated by using the Kaplan-Meier method, and median and 2-year overall survival along with 95\%CI was reported. Associations between overall survival and potential prognostic factors were assessed by using the log-rank test in unavailable analysis. Variables were found to be significant if the two-sided $\mathrm{P}$ value was $<0.05$ on univariate testing. The Cox proportional hazards model was subsequently applied in multivariable analysis by using a step-wise procedure with a level of 0.25 for entering and removing variables. The variables that reached statistical significant in this model were then deemed to be independent predictors of the outcome concerning the overall survival.

\section{RESULTS}

\section{Patient characteristics and outcomes}

Baseline characteristics of patients are shown in Table 1. The follow-up time of this study was 60 months. At the time of analysis, 210 patients died during follow-up. The 
median overall survival of patients was 29.1 months $(95 \% \mathrm{CI}=17.1$ to 41.3 months), and the 5-year survival rate of the patients was $37.5 \%$ (Figure 1). Patients who underwent nephrectomy had a lower risk of death from RCC, and patients with anemia, hypercalcemia, neutrophilia and platelet count $>400 \times 10^{9} / \mathrm{L}$ as well as Karnofsky performance status (KPS) $\geq 60$ had a higher risk of death. For VEGF polymorphism, we found that those carrying the -2578CA and AA genotypes had increased risk of death from RCC, with HR (95\% CI) of 2.17 (1.27-3.73) and 2.99 (1.51-6.09), respectively. Similarly, we found that those carrying the $-1154 \mathrm{AA}$ genotype had a greatly increased risk of death from RCC, with HR $(95 \% \mathrm{CI})$ of $5.12(1.67-20.82)$.

Table 1. Univariate analysis of demographic and clinic characteristics of study patients.

\begin{tabular}{|c|c|c|c|c|}
\hline \multirow[t]{2}{*}{ Variables } & \multicolumn{2}{|c|}{ Patients } & \multirow[t]{2}{*}{ Five-year survival rate $(\%)$} & \multirow[t]{2}{*}{ Hazard ratio $(95 \% \mathrm{CI})$} \\
\hline & $\begin{array}{c}\text { Total } \\
(\mathrm{N}=336)\end{array}$ & $\begin{array}{c}\text { Died } \\
(\mathrm{N}=210)\end{array}$ & & \\
\hline \multicolumn{5}{|l|}{ Age (years) } \\
\hline$<40$ & 47 & 32 & 32.6 & 1.0 (Ref.) \\
\hline $40-49$ & 79 & 52 & 34.3 & $0.98(0.56-1.74)$ \\
\hline $50-59$ & 103 & 61 & 41.0 & $0.87(0.51-1.52)$ \\
\hline$\geq 60$ & 107 & 66 & 38.7 & $0.91(0.53-1.57)$ \\
\hline \multicolumn{5}{|l|}{ Gender } \\
\hline Male & 247 & 150 & 39.2 & 1.0 (Ref.) \\
\hline Female & 89 & 60 & 32.8 & $1.1(0.75-1.60)$ \\
\hline \multicolumn{5}{|l|}{ Nephrectomy } \\
\hline No & 66 & 60 & 8.2 & 1.0 (Ref.) \\
\hline Yes & 270 & 150 & 44.7 & $0.51(0.37-0.87)$ \\
\hline \multicolumn{5}{|l|}{ Treatment } \\
\hline Sunitinib & 206 & 128 & 38.0 & 1.0 (Ref.) \\
\hline Sorafenib & 97 & 55 & 43.1 & $0.92(0.62-1.35)$ \\
\hline Bevacizumab & 33 & 27 & 17.7 & $1.43(0.77-2.61)$ \\
\hline \multicolumn{5}{|c|}{ VEGF targeted therapy } \\
\hline First line & 217 & 139 & 35.9 & 1.0 (Ref.) \\
\hline Second line & 119 & 71 & 40.5 & $0.93(0.65-1.32)$ \\
\hline \multicolumn{5}{|l|}{ Anemia } \\
\hline No & 113 & 52 & 54.1 & 1.0 (Ref.) \\
\hline Yes & 223 & 158 & 29.1 & $1.52(1.04-2.25)$ \\
\hline \multicolumn{5}{|l|}{ Hypercalcemia } \\
\hline No & 298 & 175 & 41.4 & 1.0 (Ref.) \\
\hline Yes & 38 & 35 & 6.5 & $1.61(1.02-2.53)$ \\
\hline \multicolumn{5}{|l|}{ Neutrophilia } \\
\hline No & 294 & 173 & 41.3 & 1.0 (Ref.) \\
\hline Yes & 42 & 37 & 10.8 & $1.57(1.03-2.41)$ \\
\hline \multicolumn{5}{|l|}{ Thrombocytosis } \\
\hline No & 284 & 172 & 39.4 & 1.0 (Ref.) \\
\hline Yes & 52 & 38 & 27.1 & $1.20(0.76-1.88)$ \\
\hline \multicolumn{5}{|c|}{ Karnofsky performance status } \\
\hline$<60$ & 97 & 84 & 13.6 & 1.0 (Ref.) \\
\hline$\geq 60$ & 239 & 126 & 47.2 & $0.61(0.43-0.87)$ \\
\hline \multicolumn{5}{|l|}{ Histology } \\
\hline Non-clear cell & 25 & 21 & 15.8 & 1.0 (Ref.) \\
\hline Clear cell & 311 & 189 & 39.3 & $0.74(0.41-1.37)$ \\
\hline \multicolumn{5}{|c|}{ Platelet count $>400 \times 10^{9} / \mathrm{L}$} \\
\hline No & 72 & 28 & 60.6 & 1.0 (Ref.) \\
\hline Yes & 264 & 182 & 31.2 & $1.77(1.11-2.90)$ \\
\hline \multicolumn{5}{|c|}{ Lymphocytes $>160 \mathrm{~g} / \mathrm{L}$} \\
\hline No & 63 & 30 & 51.9 & 1.0 (Ref.) \\
\hline Yes & 273 & 180 & 34.2 & $1.38(0.84-2.31)$ \\
\hline
\end{tabular}




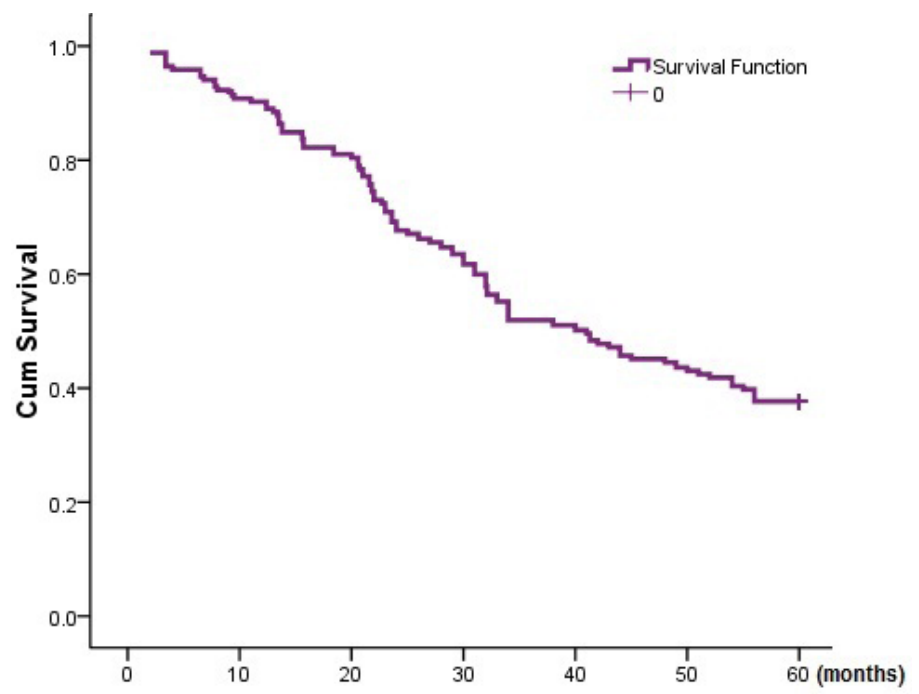

Figure 1. Overall survival probability of renal cell carcinoma patients.

\section{Multivariable analysis results}

All the potential predictive values for the survival of RCC are shown in Table 2. Although many factors were associated with individuals with RCC by univariate analysis, only five factors were identified as independent predictors of the outcome by multivariate analysis. Our study showed that KPS $\geq 60$ could delay death from RCC, with HR $(95 \% \mathrm{CI})$ of $0.57(0.39$ 0.84 ). Patients with anemia, platelet count $>400 \times 10^{9} / \mathrm{L}$, neutrophilia and lymphocytes $>160$ $\mathrm{g} / \mathrm{L}$ increased the risk of death from RCC, with HR (95\%CI) of 1.84 (1.18-2.96), 2.01 (1.27$3.25), 1.65(1.03-2.56)$ and $1.49(0.99-2.71)$, respectively. The VEGF -2578AA and -1154AA genotypes were significantly associated with a poor overall survival of RCC patients, with HR $(95 \% \mathrm{CI})$ of $2.41(1.32-5.13)$ and 3.77 (1.42-15.67), respectively.

\section{Table 2. Multivariable analysis of predictive value for the survival of renal cell carcinoma.}

\begin{tabular}{lccc}
\hline Predictive value & Hazard ratio & $95 \% \mathrm{CI}$ & $\mathrm{P}$ \\
\hline Karnofsky performance status & & & \\
$<60$ & 1.0 (Ref.) & - & 0.004 \\
$\geq 60$ & 0.57 & $0.39-0.84$ & \\
Anemia & 1.0 (Ref.) & - & 0.022 \\
$\quad$ No & 1.84 & $1.18-2.96$ & \\
$\quad$ Yes & 1.0 (Ref.) & - & 0.013 \\
Platelet count $>400 \times 109 / \mathrm{L}$ & 2.01 & $1.27-3.25$ & \\
$\quad$ No & 1.0 (Ref.) & - & 0.036 \\
$\quad$ Yes & 1.77 & $1.06-2.92$ & \\
Hypercalcemia & 1.0 (Ref.) & - & 0.047 \\
$\quad$ No & 1.65 & $1.03-2.56$ & \\
Yes & 1.0 (Ref.) & - & 0.037 \\
Neutrophilia & 1.49 & $0.99-2.71$ & \\
$\quad$ Yo & & & \\
Lymphocytes $>160 \mathrm{~g} / \mathrm{L}$ & & \\
$\quad$ No & & & \\
Yes & &
\end{tabular}




\section{DISCUSSION}

Genetic factors can affect the development of RCC, which in turn influence the incidence rate of carcinoma or carcinoma progression. Genes implicated in angiogenesis could be candidates for tumor progression and important prognostic factors in various cancers, such as breast cancer and colorectal cancer (Oh et al., 2013; Absenger et al., 2013). VEGF, a growth factor that regulates angiogenesis, is regarded as the most potent stimulatory cytokine stimulating tumor angiogenesis and an important factor for metastasis, survival and spread of the tumor (Salven et al., 1997). Several polymorphisms in the VEGF gene have been identified recently, and $-2578 \mathrm{C} / \mathrm{A},-1154 \mathrm{G} / \mathrm{A}$ and $-634 \mathrm{C} / \mathrm{G}$ at the promoter region of VEGF may have a role in altering gene transcription and may affect its expression (Oh et al., 2013; Absenger et al., 2013). Our study found that the VEGF -2578C/A and -1154G/A polymorphisms are correlated with tumor stage and tumor size, and associated with shorter survival time of RCC patients.

These results suggest that the VEGF -2578C/A and -1154G/A gene polymorphisms may be associated with increased expression of VEGF, which promotes tumor angiogensis, thus resulting in a higher tumor stage and decreased survival time of RCC patients. Therefore, VEGF gene polymorphisms could play a critical role in altering VEGF expression and influence the progression of RCC and patient survival. Previous studies have reported similar results in line with our study regarding the association between these polymorphisms of the VEGF gene and various diseases (Kawai et al., 2007). Hefler et al. (2007) demonstrated that VEGF $-634 \mathrm{C} / \mathrm{G},-1154 \mathrm{G} / \mathrm{A}$, and $-2578 \mathrm{C} / \mathrm{A}$ polymorphisms were associated with increased VEGF expression, and associated with a shortened survival time of ovarian cancer patients. Another in vitro study indicated that the $-2578 \mathrm{C}$ allele was correlated with higher levels of VEGF production (Shahbazi et al., 2002). Our study indicated that VEGF polymorphisms are associated with prognosis of RCC, which is in line with previous studies.

In our study, we showed that the prognostic factors in advanced RCC patients included high platelet, neutrophil and lymphocyte counts. These factors are inflammation markers, and these factors could be better predictors for the survival of RCC patients. A previous study showed that platelets and neutrophils were independent factors for the prognosis of advanced RCC, where patients who had elevated platelet counts had significantly shorter median survival time (8.4 months) than patients who had a normal count (14.6 months) (Choueiri et al., 2006). The mechanism of platelets in the prognosis of RCC could be that platelet overproduction can lead to enhanced adherence of malignant cells to the endothelial wall and penetration, and that platelet granules contain a variety of angiogenic factors, such as VEGF, platelet-derived growth factor, transforming growth factor $\beta$, and others that have been implicated in various steps of tumor progression (Mohle et al., 1997; O'Byrne et al., 1999). The increased neutrophils could result in overproduction of interleukins and other growth factors by the tumor (Hollen et al., 1992).

There are two limitations in our study. First, there might be limitations in the generalization of the study results, since our study results are different from studies conducted in the United States and Canada (Choueiri et al., 2006; Heng et al., 2009; Motzer et al., 2009). The different results might have been due to differences in ethnicities, treatment methods, patients' situation or by chance. Therefore, further studies in the Chinese population are warranted. Second, previous studies showed that there may be other genes involved in the prognosis of $\mathrm{RCC}$, and investigation of the association between gene polymorphism and prognosis of RCC is needed. 
In conclusion, our study presented the factors regarding the prognosis of RCC patients, and high platelet and neutrophil counts, low lymphocytes, and VEGF -2578C/A and -1154G/A polymorphisms were shown to be independent factors for a lower prognosis of RCC patients. These findings may be helpful in predicting the clinical outcome of patients with RCC. Further studies are needed to confirm their clinical significance.

\section{REFERENCES}

Absenger G, Szkandera J, Stotz M, Pichler M, et al. (2013). A common and functional gene variant in the vascular endothelial growth factor a predicts clinical outcome in early-stage breast cancer. Mol. Carcinog. 52 (Suppl 1): E96-E102.

Choueiri TK, Bukowski RM and Rini BI (2006). The current role of angiogenesis inhibitors in the treatment of renal cell carcinoma. Semin. Oncol. 33: 596-606.

Hefler LA, Mustea A, Konsgen D, Concin N, et al. (2007). Vascular endothelial growth factor gene polymorphisms are associated with prognosis in ovarian cancer. Clin. Cancer Res. 13: 898-901.

Heng DY, Xie W, Regan MM, Warren MA, et al. (2009). Prognostic factors for overall survival in patients with metastatic renal cell carcinoma treated with vascular endothelial growth factor-targeted agents: results from a large, multicenter study. J. Clin. Oncol. 27: 5794-5799.

Hollen CW, Henthorn J, Koziol JA and Burstein SA (1992). Serum interleukin-6 levels in patients with thrombocytosis. Leuk. Lymphoma 8: 235-241.

Hollingsworth JM, Miller DC, Daignault S and Hollenbeck BK (2006). Rising incidence of small renal masses: a need to reassess treatment effect. J. Natl. Cancer Inst. 98: 1331-1334.

Jäkel CE, Hauser S, Rogenhofer S, Müller SC, et al. (2012). Clinical studies applying cytokine-induced killer cells for the treatment of renal cell carcinoma. Clin. Dev. Immunol. 2012: 473245.

Kawai Y, Sakano S, Korenaga Y, Eguchi S, et al. (2007). Associations of single nucleotide polymorphisms in the vascular endothelial growth factor gene with the characteristics and prognosis of renal cell carcinomas. Eur. Urol. 52: 1147-1155.

Langsenlehner T, Langsenlehner U, Renner W, Krippl P, et al. (2008). Single nucleotide polymorphisms and haplotypes in the gene for vascular endothelial growth factor and risk of prostate cancer. Eur. J. Cancer 44: 1572-1576.

Mathew A, Devesa SS, Fraumeni JF Jr and Chow WH (2002). Global increases in kidney cancer incidence, 1973-1992. Eur. J. Cancer Prev. 11: 171-178.

Mohle R, Green D, Moore MA, Nachman RL, et al. (1997). Constitutive production and thrombin-induced release of vascular endothelial growth factor by human megakaryocytes and platelets. Proc. Natl. Acad. Sci. U. S. A. 94: 663-668.

Motzer RJ, Bander NH and Nanus DM (1996). Renal-cell carcinoma. N. Engl. J. Med. 335: 865-875.

Motzer RJ, Hutson TE, Tomczak P, Michaelson MD, et al. (2007). Sunitinib versus interferon alpha in metastatic renalcell carcinoma. N. Engl. J. Med. 356: 115-124.

Motzer RJ, Hutson TE, Tomczak P, Michaelson MD, et al. (2009). Overall survival and updated results for sunitinib compared with interferon alpha in patients with metastatic renal cell carcinoma. J. Clin. Oncol. 27: 3584-3590.

O’Byrne KJ, Dobbs N, Propper D, Smith K, et al. (1999). Vascular endothelial growth factor platelet counts, and prognosis in renal cancer. Lancet 353: 1494-1495.

Oh SY, Kwon HC, Kim SH, Lee S, et al. (2013). The relationship of vascular endothelial growth factor gene polymorphisms and clinical outcome in advanced gastric cancer patients treated with FOLFOX: VEGF polymorphism in gastric cancer. BMC Cancer 13: 43.

Patard JJ, Pouessel D, Bensalah K and Culine S (2008). Targeted therapy in renal cell carcinoma. World J. Urol. 26: $135-140$.

Sáenz-López P, Vazquez F, Cozar JM, Carretero R, et al. (2013). VEGF polymorphisms are not associated with an increased risk of developing renal cell carcinoma in Spanish population. Hum. Immunol. 74: 98-103.

Salven P, Teerenhovi L and Joensuu H (1997). A high pretreatment serum vascular endothelial growth factor concentration is associated with poor outcome in non-Hodgkin's lymphoma. Blood 90: 3167-3172.

Shahbazi M, Fryer AA, Pravica V, Brogan IJ, et al. (2002). Vascular endothelial growth factor gene polymorphisms are associated with acute renal allograft rejection. J. Am. Soc. Nephrol. 13: 260-264.

Vrdoljak E, Rini B, Schmidinger M, Omrcen T, et al. (2013). Bisphosphonates and vascular endothelial growth factortargeted drugs in the treatment of patients with renal cell carcinoma metastatic to bone. Anticancer Drugs 24: 431-440. 